Research Article

\title{
White Kabesak (Acacia leucophloea RoxB) Leaves Utilization in Concentrate on Fermentation Products and In Vitro Gas Production
}

\author{
Emma Dyelim Wie Lawa ${ }^{1 *}$, Siti Chuzaemi ${ }^{2}$, Hartutik $^{2}$, Marjuki ${ }^{2}$ \\ ${ }^{1}$ Faculty of Animal Husbandry, Nusa Cendana University, Kupang 5115, Indonesia \\ ${ }^{2}$ Faculty of Animal Husbandry, Brawijaya University, Malang 65145, Indonesia
}

Article history:

Submission February 2020

Revised May 2020

Accepted May 2020

*Corresponding author:

E-mail:

emmalawa@staf.undana.ac.id

\begin{abstract}
This study aimed to evaluate gas production and in vitro fermentation products from feed containing leaves of white kabesak (Acacia leucophloea Roxb. Willd). Feed was composed of a ratio of $60 \%$ natural grasses and $40 \%$ concentrate. The treatments were used levels of white kabesak leaves in concentrates i.e. 0, 10, 20, 30 and $40 \%(v / v)$ in the dry matter (DM) basis as treatments, $R_{0}, R_{1}, R_{2}, R_{3}$ and $\mathrm{R}_{4}$ treatments, respectively. The results showed that inclusion of $A$. leucophloea leaves in concentrate increased organic matter and crude fiber contents but decreased the crude protein content. Increasing level of A. leucophloea leaves in concentrate decreased gas production $(\mathrm{ml} / 500 \mathrm{mg} \mathrm{DM})$ from $198.29\left(\mathrm{R}_{0}\right)$ to $139.93\left(\mathrm{R}_{4}\right)$. The gas production rate ( $\mathrm{ml} /$ hour) was relatively constant between 0.034 to 0.036 on $\mathrm{R}_{0}-\mathrm{R}_{3}$ and 0.028 on $\mathrm{R}_{4}$. Gas production at 48 hours incubation (ml/500 mg DM) decreased from $153.38\left(\mathrm{R}_{0}\right)$ to $103.23\left(\mathrm{R}_{4}\right)$. The $\mathrm{NH}_{3}$ concentrations ranged from $6.17-7.31 \mathrm{mg} / 100 \mathrm{ml}$ and the total VFA was $83.07-91.96 \mathrm{mM}$. The lowest C2 / C3 ratio was in $\mathrm{R}_{2}$ (2.63). The highest IVDMD was 50.18-67.14\% in $\mathrm{R}_{0}$ and the lowest IVOMD was $55.04-71.35 \% \mathrm{R}_{4}$. The use of Acacia leucophloea leaves at level $20 \%$ in concentrates as supplements was more efficient in reducing gas production and in vitro fermentation products.
\end{abstract}

Keywords: Acacia leucophloea, Concentrate, Gas production, In vitro, Fermentation products

\section{Introduction}

Low quality of feed nutrients is often reported to be the main factor affecting the productivity of ruminant animals in the tropics, especially in eastern Indonesia including Timor. Legumes supplementation provides protein and thus can increase animal production. The high CP content in these species is an advantage to rumen microbes that depend on dietary source of nitrogen to build up their body protein [1]. The tree species are important due to their high protein content, their contribution with easy fermentation carbohydrates and fibber of better degradability, as well as their positive effect on the use of nitrogen $(\mathrm{N})$ within rumen [2]. Previous study reported that Bali cattle maintained only on low quality hay during dry season had a decreased in body weight [3], as a result of exten- sive system where the animals are left to graze in the pasture without any nutrition management from farmers.

Legumes supplementation is one of the strategies to increase animal production since it is high in crude protein and it is mainly available in Timor. In addition, legumes supplementation will reduce the cost production compared to the use of commercial concentrates. Bunglavan and Dutta (2013) stated that concentrates fed to animals resulted in inefficiency of its utilization in the rumen as well as it is expensive and thus should be reduced or prevented [4]. Forages have supplied the most economical feeds for ruminants and with the increasing price of grain feeds, forage has become much more important as a feed resource, since it cuts down feed cost, thereby reducing the total

\section{How to cite:}

Lawa EDW, Chuzaemi S, Hartutik, Marjuki (2020) White Kabesak (Acacia leucophloea RoxB) Leaves Utilization in Concentrate on Fermentation Products and In Vitro Gas Production. Journal of Tropical Life Science 10 (3): 235 - 241. doi: 10.11594/jtls.10.03.07. 
cost of animal production [5].

Acacia leucophloea Roxb. Willd. (A. leucophloea) with the local name "kabesak putih" is a legume tree that has adapted to the environment in Timor and has been used to feed cattle and goats in the area. The crude protein content of A. leucophloea found in the leaves was reported ranges from $15-17 \%$ [6], and has the ability to support natural grass as a basal diet for ruminants. The use of A. leucophloea as ruminant feed, however, has not been intensively utilised by farmers in Timor and thus evaluation about its potential is still limited. Although A. leucophloea has been used as a supplement for ruminants but only based on the experience and without nutritional considerations. Therefore, the purpose of this study was to determine the potential of A. leucophloea in concentrate as a supplement on fermentation and in vitro gas production.

\section{Material and Methods \\ Leaves of Acacia leucophloea}

The A. leucophloea leaves used in this study were collected from A. leucophloea trees around Kupang city, East Nusa Tenggara province. The leaves were then sundried for 3-4 days until air dry and ground into flour before used for chemical analysis. The nutrient content of A. leucophloea leaves were $90.22 \% \mathrm{DM}, 6.68 \%$ ash, $14.72 \% \mathrm{CP}$, $30.40 \%$ fibre, $0.01 \%$ EE, NFE $48.19 \%$.

\section{Chemical analysis}

The dry matter of the sample was determined by oven-dried at $105^{\circ} \mathrm{C}$ overnight and the ash content was determined by burning the feed sample in the furnace at $600^{\circ} \mathrm{C}$ for 8 hours. The chemical analysis was performed following procedures of AOAC [7]. Van Soest analysis was used for determining acid detergent fiber (ADF) and neutral detergent fiber (NDF) [8]. Condensed tannin, total tannin and total phenol analysis was following the method of the Vanillin-HCl [9].

\section{In vitro gas production}

An amount of five hundred milligrams of feed samples (60\% grass: $40 \%$ concentrate) were weighed and put into a 100-ml syringe (Fortuna, Häberle labortechnich, Germany) with a piston that had been smeared with vaseline and the tip of the piston connected with silicone rubber and then covered with a plastic clip. The concentrate con- sists of $5 \%$ soybean meal, $8 \%$ coconut cake, $15 \%$ rice bran, $12 \%$ finely ground corn. The dietary treatments were: $40 \%$ concentrate: $0 \%$ leaves $A$. leucophloea (R0); $30 \%$ concentrate: $10 \%$ leaves A. leucophloea (R1); 20\% concentrate: 20\% leaves A. leucophloea (R2); 30\% concentrate: $10 \%$ leaves A. leucophloea (R3) and $40 \%$ leaves A. leucophloea: $0 \%$ concentrate (R4).

Rumen fluid was collected from a cross-breed FH cow fed corn forage (CP 9.37\%) as much as 10-12 kg and concentrates (PAP milk, CP 16\%), and water was provided ad libitum. The rumen liquid was collected in a pre-warmed thermos flask and filtered through 4-layers of gauze. The rumen liquid was mixed with a buffer solution in a ratio of $1: 4(\mathrm{v} / \mathrm{v})$. The buffer solution used consisted of $\mathrm{NaHCO}_{3}+\mathrm{Na}_{2} \mathrm{HPO}_{4}+\mathrm{KCl}+\mathrm{NaCl}+$ $\mathrm{MgSO}_{4} \cdot 7 \mathrm{H}_{2} \mathrm{O}+\mathrm{CaCl}_{2} \cdot 2 \mathrm{H}_{2} \mathrm{O}$. The mixture was kept stirred under $\mathrm{CO}_{2}$ at $39^{\circ} \mathrm{C}$, by using a magnetic stirrer fitted with a hot plate, under continuous flushing with $\mathrm{CO}_{2}$. A portion $(50 \mathrm{ml})$ of the buffer mixture with rumen fluid was transferred into the syringe containing the feed sample and then incubated in a water bath (Ehret brand) at $39^{\circ} \mathrm{C}$ for 48 hours.

The method used for in vitro gas production was based on the techniques described by Makkar et al. [10]. Gas production was recorded at 0, 2, 4, $8,12,24$ - and 48-hours post incubation using a syringe equipped with a needle. Shaken was performed every 1 hour after incubation. The rate and production of gas are determined for each treatment according to the modified model of the equation of Ørskov and McDonald [11] as follows:

$$
Y=b\left(1-e^{-c t}\right)
$$

Where:

$\mathrm{Y}$ : the volume of gas production at the time " $\mathrm{t} "$

b : potential gas production (ml/g DM) of insoluble fractions

c : constant gas production rate (h-1) for insoluble fractions (b)

$\mathrm{t}$ : incubation time

After 48 hours incubation, the syringe was removed and cooled in a container of cold water for 30 minutes. The contents of the syringe were removed and put in a fermenter tube. The $\mathrm{pH}$ values were measured using a digital $\mathrm{pH}$ meter (SchottHandylab 1). Sub samples of mixed rumen buffer 
Table 1. Feed ingredients and chemical composition of experimental diets

\begin{tabular}{|c|c|c|c|c|c|c|c|c|c|}
\hline \multirow{2}{*}{$\begin{array}{c}\text { Chemical } \\
\text { composition* }\end{array}$} & \multicolumn{9}{|c|}{ Treatments } \\
\hline & $\mathrm{R}_{0}$ & \multicolumn{2}{|l|}{$\mathrm{R}_{1}$} & \multicolumn{2}{|c|}{$\mathrm{R}_{2}$} & \multicolumn{2}{|c|}{$\mathrm{R}_{3}$} & \multicolumn{2}{|c|}{$\mathrm{R}_{4}$} \\
\hline Dry matter (\%) & 89.77 & \multicolumn{2}{|c|}{89.89} & \multicolumn{2}{|c|}{89.84} & \multicolumn{2}{|c|}{89.88} & \multicolumn{2}{|c|}{90.06} \\
\hline $\begin{array}{l}\text { Organic matter } \\
(\%)\end{array}$ & 87.89 & \multicolumn{2}{|c|}{87.86} & \multicolumn{2}{|c|}{88.19} & \multicolumn{2}{|c|}{88.47} & \multicolumn{2}{|c|}{88.5} \\
\hline Crude protein (\%) & 12.14 & \multicolumn{2}{|c|}{12.13} & \multicolumn{2}{|c|}{12.25} & \multicolumn{2}{|c|}{12.38} & \multicolumn{2}{|c|}{11.72} \\
\hline Crude fiber (\%) & 27.9 & \multicolumn{2}{|c|}{28.32} & \multicolumn{2}{|c|}{28.64} & \multicolumn{2}{|c|}{31.21} & \multicolumn{2}{|c|}{34.54} \\
\hline \multirow{2}{*}{$\begin{array}{c}\text { A. leucophloea } \\
\text { leaves }\end{array}$} & $\begin{array}{l}\text { Total } \\
\text { tannin** }\end{array}$ & $\begin{array}{l}\text { Condensed } \\
\text { tannin** }\end{array}$ & $\begin{array}{l}\text { Total } \\
\text { fenol** }\end{array}$ & $\mathrm{NDF}$ & $\mathrm{ADF}$ & Cellulose & $\begin{array}{l}\text { Hemi- } \\
\text { cellulose }\end{array}$ & Lignin & Silica \\
\hline & 0.97 & 0.49 & 3.52 & 46.8 & 34.8 & 23.55 & 11.98 & 9.83 & 0.45 \\
\hline
\end{tabular}

Note:

*Animal Nutrition Laboratory, Faculty of Animal Husbandry, Brawijaya University

**Laboratory of BPT Ciawi Bogor, 2015

$\mathrm{R}_{0}=40 \%$ concentrate: $0 \%$ leaves $A$. leucophloea, $\mathrm{R}_{1}=30 \%$ concentrate: $10 \%$ leaves $A$. leucophloea; $\mathrm{R}_{2}=20 \%$ concentrate: $20 \%$ leaves A. leucophloea; $\mathrm{R}_{3}=30 \%$ concentrate: $10 \%$ leaves A. leucophloea and $\mathrm{R}_{4}=40 \%$ leaves A. leucophloea: $0 \%$ concentrate.

$(0.6 \mathrm{ml})$ were added $3 \mathrm{ml}$ of methaposporic acid solution, then centrifuged at $9000 \mathrm{rpm}$ for 15 minutes, and the supernatant was stored at $-20^{\circ} \mathrm{C}$ before VFA analysis by using gas chromatography. The amount of $1 \mathrm{ml}$ of sub-sample was prepared and analysed for NH3 concentration by using the Conway method [12]. Samples were removed from the syringe and filtered using Whatman paper $41 \Phi 0.11 \mathrm{~mm}$ which was previously heated in a $105^{\circ} \mathrm{C}$ oven for 12 hours, then cooled in an exicator and weighed. The dish containing feed residue sample was mixed with a neutral detergent solution and then rinsed and dried. The DM digestibility and OM digestibility values were obtained by subtracting DM and OM residues from their initial DM and OM amounts before incubation, respectively.

\section{Statistical analysis}

Data obtained from this study were analysed using analysis of variance (ANOVA) to compare fermentation products (total $\mathrm{NH}_{3}$, total VFA and partial VFA, DM digestibility and OM digestibility as well as in vitro gas production using the General Linear Model (GLM) of Statistics for Windows (1993). The difference between treatments was followed by Duncan test [13].

\section{Results and Discussions Feed chemical analysis}

The nutrient content of the feed in each treat- ment showed an iso-protein, where the crude protein of each treatment was compiled to meet $\mathrm{CP}$ $12 \%$. Increasing levels of $A$. leucophloea leaves in feed increased the organic matter and crude fiber content but tends to decrease the crude protein content. The proximate analysis results and Van Soest of A. leucophloea leaves are presented in Table 1. Total tannin, condensed tannin and total phenol were low compared to other legume plants. The content of condensed tannin (CT) in Acacia tortilis (22.52\%), Acacia galpinii (22.72\%), Acacia sieberiana (1.68\%), and Acacia hebeclada (1.56\%) [14]. The content of secondary compounds in each legume plant is varied.

\section{Gas production}

Increasing the level of $A$. leucophloea leaves in the treatments had significantly affect $(\mathrm{P}<0.05$ gas production values (Table 2). The highest gas production was achieved by treatment R0 (198.29 $\mathrm{ml})$ and the lowest one was in $\mathrm{R} 4(139.93 \mathrm{ml})$. The potential yield of gas produced indicated that inclusion of A. leucophloea leaves in treated feed had higher feed quality than when feed without $A$. leucophloea leaves. Increasing the level of A. leucophloea leaves increased the crude fiber content as well as the tannin content indirectly which causes the components of organic matter being difficult to be digested and resulting in decreases of gas production. This is in line with findings of Jayanegara and Sofyan [15], that high amounts of 
Table 2. Mean values of gas production (b), potential gas production rate of insoluble fractions (c), and gas production $48 \mathrm{~h}$ incubation (y) of A. leucophloea treatment

\begin{tabular}{|c|c|c|c|c|c|}
\hline \multirow[t]{2}{*}{ Variables } & \multicolumn{5}{|c|}{ Treatments } \\
\hline & $\mathrm{R}_{0}$ & $\mathrm{R}_{1}$ & $\mathrm{R}_{2}$ & $\mathrm{R}_{3}$ & $\mathrm{R}_{4}$ \\
\hline $\begin{array}{l}\text { b: Gas production } \\
\text { (ml/500 mg DM) }\end{array}$ & $198.29 \pm 35.0^{b}$ & $157.71 \pm 8.3^{\mathrm{a}}$ & $150.61 \pm 5.6^{\mathrm{a}}$ & $141.84 \pm 5.1^{\mathrm{a}}$ & $139.93 \pm 18.2^{\mathrm{a}}$ \\
\hline $\begin{array}{l}\text { c: Gas production } \\
\text { rate of insoluble } \\
\text { fractions }(\mathrm{ml} / \mathrm{h})\end{array}$ & $0.035 \pm 0.003$ & $0.034 \pm 0.004$ & $0.036 \pm 0.005$ & $0.036 \pm 0.004$ & $0.028 \pm 0.007$ \\
\hline $\begin{array}{l}\text { y: gas production } \\
48 \mathrm{~h} \text { incubation } \\
\text { (ml/500 mg DM }\end{array}$ & $153.38 \pm 6.3^{b}$ & $119.05 \pm 0.93^{\mathrm{a}}$ & $117.82 \pm 5.40^{\mathrm{a}}$ & $105.82 \pm 2.87^{\mathrm{a}}$ & $103.23 \pm 5.03^{a}$ \\
\hline $\begin{array}{l}\text { Note: } \\
\text { abc = values within a r } \\
\mathrm{R}_{0}=40 \% \text { concentrate: } \\
20 \% \text { leaves } \text { A. leucoph } \\
\text { concentrate }\end{array}$ & $\begin{array}{l}\text { with different su } \\
\text { leaves A. leucop } \\
a ; \mathrm{R}_{3}=30 \% \text { cor }\end{array}$ & $\begin{array}{l}\text { cripts differ: } \mathrm{P}< \\
\text { ea, } \mathrm{R}_{1}=30 \% \text { con } \\
\text { trate: } 10 \% \text { leave }\end{array}$ & rate: $10 \%$ leaves & $\begin{array}{l}\text { leucophloea; } \mathrm{R}_{2} \\
4=40 \% \text { leaves }\end{array}$ & 0\% concentrate: \\
\hline
\end{tabular}

tannin in plants can decrease the ability of rumen microbes to degrade carbohydrates and proteins and inhibited enzyme activity. Amnifard et al. [16], reported that the b value of soybean meal incubated in rumen fluid containing corn silage (control) was significantly higher than if incubated in rumen fluid containing khinyuk leaves (Pistachio khinyuk) by $30 \%$ (132.36 ml/300 mg DM vs $116.2 \mathrm{ml} / 300 \mathrm{mg} \mathrm{DM})$.

A low value of $\mathrm{b}$ in $\mathrm{R} 4$ compared to other treatments was due to high crude fiber content as well as high lignin content as reported by Zulkarnain et al. [17] that fiber components (cellulose and hemicellulose) affects the values of $b$ in in vitro gas production.

Increasing the level of leaf A. leucophloea in the treatment had no effect on gas production rate of insoluble fraction (value c), but had increased $(\mathrm{P}<0.05)$ gas production after 48 hours incubation (y value). Concentrate treatment without $A$. leucophloea (R0) had higher gas production of 48 hours incubation than the treatments with the addition of A. leucophloea leaves (R1, R2, R3, and R4). The highest gas production at R0 was $153.38 \mathrm{ml} / 500$ $\mathrm{mg} \mathrm{DM}$ and the lowest was in treatment (103.23 $\mathrm{ml} / 500 \mathrm{mg} \mathrm{DM}$ ). The results shown in treatment R4 reflect the characteristics of A. leucophloea leaves as a single concentrate feed. Makkar et al. (2007) indicated that the ability of tannin to interact with feed components, especially protein and crude fiber was largely contributing to the amount of gas production [18]. Sallam et al. [19], suggest that high NDF, ADF and phenolic compounds can limit the in vitro fermentation. The relationship between 48 hours incubation and gas production indicated a positive correlation in which the longer the incubation period, the higher the gas production in each treatment level of A. leucophloea in feed, as shown in Figure 1.

\section{$\mathrm{NH}_{3}, \mathrm{VFA}, \mathrm{DM}$ digestibility and $\mathrm{OM}$ digestibility Values}

The average $\mathrm{NH} 3$, total VFA and partial VFA values, DM digestibility and OM digestibility of feed at different levels of $A$. leucophloea leaves at the 48-hour incubation are listed in Table 3.

Inclusion of of $A$. leucophloea leaves in feed had significantly $(\mathrm{P}<0.05)$ affect the $\mathrm{NH}_{3}$ concentration. The concentration of $\mathrm{NH}_{3}$ in $\mathrm{R} 0$ was not different from R2 but higher than R1, R3 and R4. Treatment R2 was not different from R1 and R4, and R3 was not different from R4. Inclusion of $A$. leucophloea leaves as a single supplement (R4) resulted in decreased $\mathrm{NH} 3$ concentration, which may due to lower crude protein content and tannin concentration in R4 than the other treatments that affect the rumen fermentation. Feed fermentation in the rumen containing tannins resulted in lower $\mathrm{NH} 3$ concentrations than those without tannins content [20, 21].

Feed concentrate with $A$. leucophloea leaves had decreased $(\mathrm{P}<0.01)$ total VFA and partial VFA against the $\mathrm{C} 2 / \mathrm{C} 3$ ratio. The highest total VFA concentration was found at R0 (91.96 mM) 


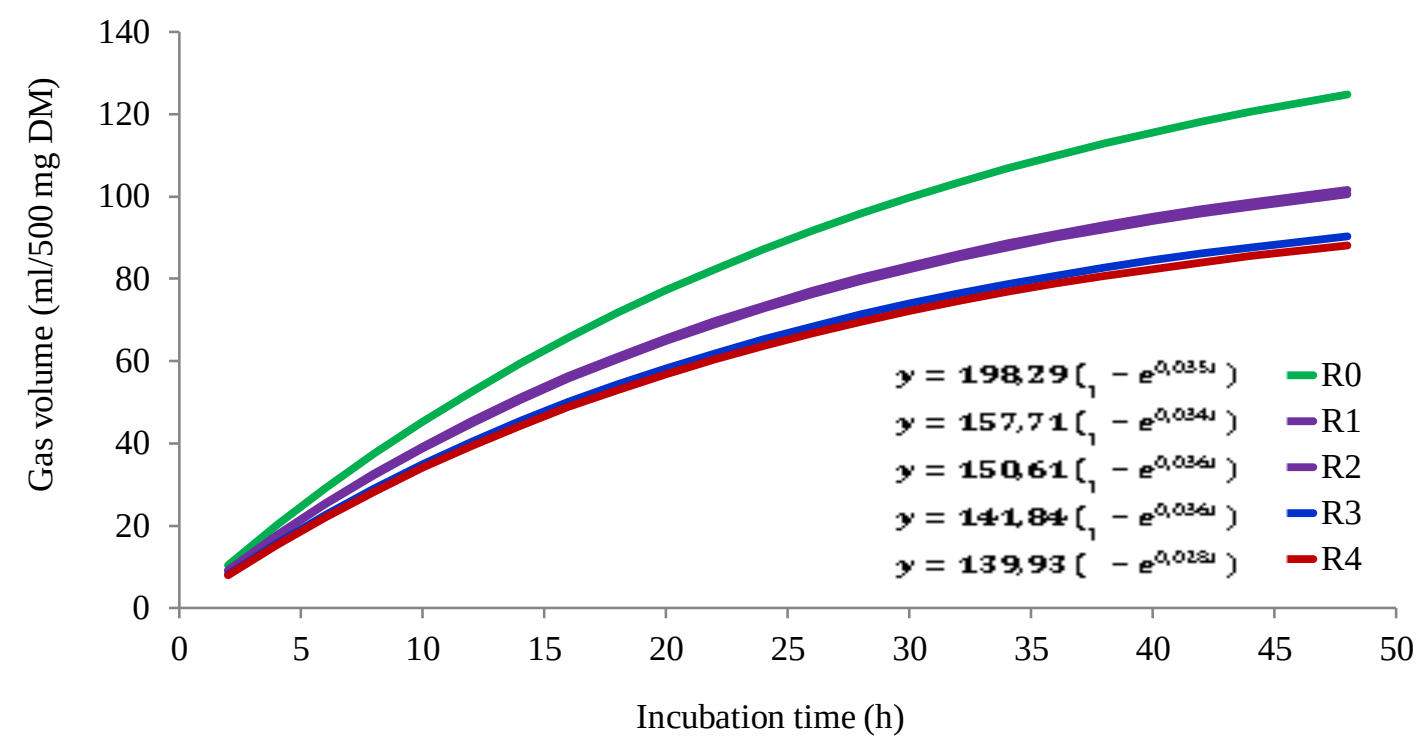

Figure 1. Effect of A. leucophloea to concentrate ratio on gas production at different time of incubation. Correlation of gas production and incubation time as follows: R0 (一) y=198.29(1-e0.035t); R1 (一) y=157.71(1-e0.034t); R2 (一) $\mathrm{y}=150.61(1-e 0.036 \mathrm{t}) ; \mathrm{R} 3(-) \mathrm{y}=141.84(1-\mathrm{e} 0.036 \mathrm{t}) ; \mathrm{R} 4(-) \mathrm{y}=139.93(1-\mathrm{e} 0.028 \mathrm{t})$

Table 3. Mean values of $\mathrm{NH}_{3}$, VFA, IVDMD and IVOMD of different level of A. leucophloea

\begin{tabular}{lccccc}
\hline \multirow{2}{*}{ Variables } & \multicolumn{5}{c}{ Treatments } \\
\cline { 2 - 6 } & $\mathrm{R}_{0}$ & $\mathrm{R}_{1}$ & $\mathrm{R}_{2}$ & $\mathrm{R}_{3}$ & $\mathrm{R}_{4}$ \\
\hline $\mathrm{NH}_{3}(\mathrm{mg} / 100 \mathrm{ml})$ & $7.31 \pm 0.51^{\mathrm{c}}$ & $6.80 \pm 0.00^{\mathrm{b}}$ & $7.06 \pm 0.16^{\mathrm{bc}}$ & $6.17 \pm 0.22^{\mathrm{a}}$ & $6.29 \pm 0.17^{\mathrm{ab}}$ \\
Total VFA (mM & $91.96 \pm 1.48^{\mathrm{b}}$ & $84.66 \pm 3.07^{\mathrm{a}}$ & $83.52 \pm 6.25^{\mathrm{a}}$ & $84.01 \pm 0.67^{\mathrm{a}}$ & $83.07 \pm 0.99^{\mathrm{a}}$ \\
$\mathrm{C} 2$ & $65.48 \pm 0.72^{\mathrm{b}}$ & $59.59 \pm 0.67^{\mathrm{b}}$ & $55.08 \pm 6.71^{\mathrm{a}}$ & $59.45 \pm 0.93^{\mathrm{ab}}$ & $58.32 \pm 1.11^{\mathrm{a}}$ \\
$\mathrm{C} 3$ & $18.48 \pm 0.78^{\mathrm{a}}$ & $17.64 \pm 1.60^{\mathrm{a}}$ & $21.04 \pm 0.90^{\mathrm{b}}$ & $18.13 \pm 0.28^{\mathrm{a}}$ & $18.71 \pm 0.18^{\mathrm{a}}$ \\
$\mathrm{C} 4$ & $8.01 \pm 0.02^{\mathrm{b}}$ & $7.43 \pm 0.81^{\mathrm{b}}$ & $7.41 \pm 0.44^{\mathrm{b}}$ & $6.44 \pm 0.01^{\mathrm{a}}$ & $6.04 \pm 0.01^{\mathrm{a}}$ \\
$\mathrm{C} 2 / \mathrm{C3}$ & $3.55 \pm \pm 0.11^{\mathrm{b}}$ & $3.39 \pm 0.27^{\mathrm{b}}$ & $2.63 \pm 0.43^{\mathrm{a}}$ & $3.28 \pm 0.10^{\mathrm{b}}$ & $3.12 \pm 0.09^{\mathrm{b}}$ \\
IVDMD & $67.14 \pm 0.73^{\mathrm{c}}$ & $65.59 \pm 0.79^{\mathrm{c}}$ & $65.89 \pm 0.21^{\mathrm{c}}$ & $56.59 \pm 0.28^{\mathrm{b}}$ & $50.18 \pm 1.88^{\mathrm{a}}$ \\
IVOMD & $71.35 \pm 1.12^{\mathrm{b}}$ & $68.27 \pm 2.74^{\mathrm{b}}$ & $68.63 \pm 1.08^{\mathrm{b}}$ & $59.20 \pm 2.80^{\mathrm{a}}$ & $55.04 \pm 3.72^{\mathrm{a}}$ \\
\hline
\end{tabular}

Note:

$\mathrm{abc}=$ values within a row with different superscripts differ: $\mathrm{P}<0.05$; VFA: volatile fatty acid; IVDMD: in vitro dry matter digestibility; IVOMD: in vitro organic matter digestibility

$\mathrm{R}_{0}=40 \%$ concentrate: $0 \%$ leaves $A$. leucophloea, $\mathrm{R}_{1}=30 \%$ concentrate: $10 \%$ leaves $A$. leucophloea; $\mathrm{R}_{2}=20 \%$ concentrate: 20\% leaves A. leucophloea; $\mathrm{R}_{3}=30 \%$ concentrate: $10 \%$ leaves $A$. leucophloea and $\mathrm{R}_{4}=40 \%$ leaves A. leucophloea: $0 \%$ concentrate

and the lowest at R4 (83.07 $\mathrm{mM})$ but the values obtained were still within the normal range of 70$150 \mathrm{mM}$ [22]. The concentration of total VFA has a positive relationship to gas production where the higher the concentration of VFA the higher the production of gas produced. In the present study, the $\mathrm{C} 2 / \mathrm{C} 3$ ratio were ranged from $2.63-3.55$. The lowest C2/C3 ratio was in R2 treatment (2.63) indicating that inclusion $20 \%$ of $A$. leucophloea leaves in concentrate was beneficial and effective to rumen microbial in producing energy and illus- trating high efficiency of fatty acids utilization.

Inclusion of A. leucophloea leaves in concentrate had significantly decreased $(\mathrm{P}<0.01) \mathrm{DM}$ digestibility and $\mathrm{OM}$ digestibility. DM digestibility and $\mathrm{OM}$ digestibility treatments in $\mathrm{R} 0$ were not different from R1 and R2 but were different from R3 and R4. These results indicated that digestibility of feed is largely influenced by the crude fiber content but not tannin content. Olivares-Perez et al. [23] reported that the ADF content, total phenol and CT had negatively correlated with forage di- 
gestibility where the higher the content in the forage, the lower the nutrient digestibility.

\section{Conclusion}

A. leucophloea leaves utilization in concentrates as supplements reduces gas production and in vitro fermentation products. Inclusion of A. leucophloea leaves at $20 \%$ in a mixture of concentrates and natural grasses resulted in more efficient gas production and fermentation products

\section{Acknowledgement}

$-$

\section{References}

1. Aderinboye RY, Akinlolu AO, Adeleke MA et al. (2016) In vitro gas production and drymatter degradation of four browse leaves using cattle, sheep and goat inocula. Slovak Journal of Animal Science 49 (1): 32-43.

2. Shamseldin HA, Jumaa MEM, Shadia AO (2017) The use of in vitro gas production technique as an index of the nutritive value of green shoot, leaves, fruits flesh and seed cakes of Ziziphus spina-christi (sidder) tree for feeding ruminants. IOSR Journal of Agriculture and Veterinary Science (IOSR-JAVS) 10 (2): 58-63.

3. Bamualim AM, Wirdahayati RB (2002) Peternakan di Lahan Kering Nusa Tenggara. Balai Pengkajian Teknologi Pertanian Nusa Tenggara Timur, Kupang.

4. Bunglavan SJ, Dutta N (2013) Use of tannins as organic protectants of proteins in digestion of ruminants. Journal of Livestock Science 4: 67-77.

5. Ojo VOA, Adeoye SA, Oni AO et al. (2017) Nutritive value of processed feed respources from natural pastures within South-west Nigeria. Archivos de Zootecnea 66 (256): 469-474.

6. Arulnathan N, Chellapandian M (2016) Chemical composition of thorny tree leaves available during dry season in North Western Zone of Tamil Nadu for goats. International Journal of Science, Environment and Technology 5 (3): $1381-1383$.

7. AOAC (2005) Official Methods of Analysis. 18th Ed., Association of Official Analytical Chemist. Arlington, VA.

8. Van Soest PJ, Robertson JB, Lewis BA (1991) Methods for fibre and non-starch polysaccharides in relation to animal nutrition. Journal of Dairy Science 74 (10): 3583 3597.

9. Makkar HPS, Becker K (1993) Vanilline-HCl method for condensed tannins: Effect of organic solvents used for extraction of tannins. Journal of Chemical Ecology 19: 613 - 621. doi: 10.1007/BF00984996
10. Makkar HPS, Blümmel M, Becker K (1987) Application of an in vitro gas method to understand the effect of natural plant products on availability and partitioning of nutrients. BSAP Occasional Publication 22: 147 - 150. doi: 10.1017/S0263967X00032432

11. Ørskov ER, McDonald I (1979) The estimation of protein degradability in the rumen from incubation measurements weighted according to rate of passage. The Journal of Agriculturak Science 92 (2): 499 - 503. doi: 10.1017/S0021859600063048

12. Conway EJ (1957) Microdiffusion analysis and volumetric error. Crosby Cockwood, London, UK.

13. Steel RGD, Torrie JH (1980) Principles and Procedures of Statistics with Special Refference to the Biological Science. McGraw Hill, New York.

14. Mokoboki HK (2011) Effect of Acacia hebeclada species within season on techniques used to measure nutritive value and anti-nutritional forages in browse tree leaves. Life Science Journal 8 (52): 112 - 119.

15. Jayanegara A, Sofyan A (2008) Penentuan aktivitas biologis tanin beberapa hijauan secara in vitro menggunakan Hohenheim gas test dengan polietilen glikol sebagai determinan. Media Peternakan 31 (1): 44 -52 .

16. Aminifard Z, Chaji M, Mohammadabadi T (2015) The replacement value of corn silage with wild pistachio (Pistachio khinyuk) leaf in the diet of sheep and its effect on digestibility of fiber and protein. Journal of Livestock Science and Technology 3 (1): 17 - 23. doi: 10.22103/JLST.2015.978.

17. Zulkarnain, Ismartoyo, Harfiah (2014) Karakteristik degradasi tiga pakan yang disuplementasi daun gamal (Gliricidia maculata) dalam rumen kambing secara in sacco. Jurnal Ilmu dan Teknologi Peternakan 3 (3): 148 $-153$.

18. Makkar, H.P.S., G. Francis \& K. Becker. 2007. Bioactivity of phytochemicals in some lesser known plants and their effects and potential applications in livestock and aquaculture production system. Animal (1) : 1371-1391.

19. Sallam SMAH, da Silva Bueno IC, de Godoy PB et al. (2010) Ruminal fermentation and tannins bioactivity of some browse using a semi-automated gas production technique. Tropical and Sub Tropical Agroecosystems 12 (1): $1-10$.

20. Meissner HH, Smith M, Niekerk WA (1993) Rumen ammonia concentration and non ammonia nitrogen passage and apparent absorbtion from the small intestine of sheep ingesting subtropical and temperate tannin containing forage. South African Journal of Animal Science 23 (3): $92-97$.

21. Frutoz P, Raso M, Hervas G et al. (2004) Is there any 
detrimental effect when a chestnut hydrolysable tannins extract is included in the diet of finishing lambs?. Animal Research, EDP Sciences 53 (2): 127 - 136.

22. McDonald P, Edwards RA, Greenhalgh JFD, Morgan CA (2002) Animal Nutrition. Pearson Education Limited, Essex CM20 2JE, England.
23. Olivares-Perez J, Aviles-Nova F, Albarran-Portillo B et al. (2014) Chemical composition of leguminous tree foliage and effect of polyethylene glycol on gas production and in vitro digestion parameters. Tropical and Subtropical Agroecosystems 17 (2):207-2014. 
This page is intentionally left blank 